\title{
Fintech terhadap Kinerja Keuangan Perbankan Syariah di Indonesia
}

\author{
Tri Damayanti \\ Universitas Gunadarma \\ t_damayanti@staff.gunadarma.ac.id \\ Muhamad Syahwildan \\ Universitas Pelita Bangsa \\ muhamad.syahwildan@pelitabangsa.ac.id
}

\begin{abstract}
This study aims to determine the effect of mobile banking, internet banking and sms banking on the financial performance of Islamic banking in Indonesia. The type of research used in this research is descriptive research with a qualitative approach. The population in this study areall financial reports published by Islamic banks that have used mobile banking, internet banking and sms banking, namely BRI Syariah, BNI Syariah, Syariah Mandiri, BCA Syariah,Bukopin Syariah and BJB Syariah and have reported their financial statements with a period of 2015-2020. The results showed that mobile banking, internet banking and sms banking hada significant effect on the financial performance of Islamic banks in Indonesia

Keywords Mobile Banking, Internet Banking, SMS Banking and Financial Performance
\end{abstract}

\section{PENDAHULUAN}

Perkembangan teknologi informasi dan komunikasi (TIK) telah merambah ke berbagai sektor dalam setiap aspek kehidupan saat ini, salah satunya yang paling fenomenal adalah pemanfaatan informasi yang diterapkan pada sektor jasa keuangan berbasis teknologi tentunya akan menganggu pasar keuangan tradisonal (Navaretti et.,al 2018; Nicoletti et al 2017). Menurut Crismastianto (2017), fintech adalah sebuah inovasi sektor keuangan yang terkait dengan teknologi modern. Aneka ragam pengembangan pemain fintech, pengakuan dan potensi regulasi komunitas yang lebih luas dengan akses keuangan, itu mungkin idenya adalah strategi yang menggabungkan perbankan syaraiah fintech. Karena kemudahannya, teknologi dapat juga membawa menjadi ancaman bagi sektor perbankan, khususnya perbankan syariah, dimana bank menyediakan cadangan dalam proses pinjam meminjam.

Penilaian terhadap kinerja bank sangat penting dilakukan karena menyangkut lepentingan banyak aspek. Hal tersebut dikarenakan bank mempunyai peran penting sebagai lembaga keuangan yang mengelola dana nasabah yang berhubungan langsung dengan masyarakat umum dalam proses operasionalnya, sehingga diperlukan menjaga kesehatan bank untuk menjaga kepercayaan masyarakat kepada perbankan. Dalam balanced scorecard terhadap empat perspektif yang digunakan untuk mengukur kinerja perusahaan. Empat persepektif tersebut adalah keuangan, pelanggan, bisnis internal, serta inovasi dan pembelajaran. 
Tujuan dari penelitian yang ingin dicapai adalah untuk mengetahui sampai sejauh mana pengaruh Fintech terhadap kinerja keuangan perbankan syariah di Indonesia. Beberapa penelitian terdahulu telah melakukan penelitian terhadap fintech pada kinerja keuangan perbankan syariah di Indonesia dengan menggunakan rasio keuangan yang berbeda-beda serta tahun laporan keuangam yang berbeda- beda. Seperti penelitian yang Yulia Prastika (2019), menemukan bahwa layanan fintech dapat meningkatkan profitabilitas perbankan syariah serta memudahkan masyarakat dalam menteknologi tentunya akan gakses perbankan syariah.

\section{LANDASAN TEORI Financial Technology}

Fintech adalah istilah yang sangat populer dengan berbagai defenisi yang saat ini tidak ada kesepakatan (Schueffel, 2017 ; Thakor, 2020). Fintech didefinisikan dalam arti sempit sebagai penggunaan teknologi untuk memecahkan masalah keuangan (Arner et al., 2015). Juga didefinisikan sebagai penggunaan penerapan teknologi digital untuk memecahkan masalah intermediasi keuangan (Aaron et al., 2017). Fintech secara luas didefiniskan sebagai inovasi teknologi keuangan yang menghasilkan model bisnis, aplikasi, proses, atau produk baru dengan efek material yang terkait dengan lembaga keuangan dan penyediaan jasa keuangan (FBS, 2017).

\section{Perbankan Syariah}

Perbankan syariah telah berkembang pesat dalam beberapa dekade terakhir. Bank- bank islam memainkan peran utama di negara-negara yang didominasi muslim, tetapi mereka juga beroperasi di beberapa negara eropa seperti Inggris, Prancis, Luksemburg dan Afrika Selatan meskipun negara-negara tersebut memiliki populasi muslim yang relatif rendah (Hussain dan Turk-Ariss 2015). Sesuai dengan Undang-Undang Nomor 21 Tahun 2008 Pasal 1, perbankan syraiah adalah segala sesuatu entang bank syariah dan unit usaha syariah, termasuk lembaga usah, serta cara dan proses dalam menjalankan kegiatan usahanya. Bank syariah adalah bank yang melakukan kegiatan usaha berdasarkan prinsip syariah. Aturan syariah dijelaskan dalam UU 10 Tahun 1998, yaitu aturan syariah adalah aturan perjanjian bedsarkan hukum islam antara bank dengan pihak lain untuk tujuan menyimpan dana dan atau menbiayai usaha atau kegiatan lain yang diatur dalam hukum syariah. Pembiayaan berdasarkan prinsip syariah, prinsip agi hasil (mudharabah), pembiayaan berdasarkan prinsip pentertaan modal (musyarakah), prinsip jual beli barang dengan keuntungan (Muharabahah), dan pembiayaan barang modal berdasarkan prinsip syariah.

\section{Rasio Keuangan}

Menurut Kasmir (2014), analisis rasio keuangan adalah kegiatan membandingkan angkaangka dalam laporan keuangan. Perbandinagan dapat dilakukan antara satu laporan keuangan, atau unsur-unsur yang ada antar laporan keuangan. Selain itu, angka-angka yang akan dibandingkan dapat berupa angka-angka yang akan dibandingkan dapat berupa angka- angka dalam satu periode atau lebih. Sedangkan pengertian analisis indikator keuangan menurut Irham (2012) adalah alat indikator untuk mengetahui kondisi keuangan suatu perusahaan. Investor jangka panjang pendek dan kemampuan perusahaan untuk membayar dividen yang sesuai. Informasi ini diperolehbila diperlukan dari hasil analisis rasio keuangan. 


\section{METODE PENELITIAN}

Pendekatan yang digunakan dalam penelitian ini adalah pendekatan kualitatif adalah metode filosofi posivisme. Dalam penelitian ini menggunakan data sekunder. Data sekunder merupakan data yang diperoleh dari resgister dan majalah berupa laporan keuangan, publikasi perusahaan, laporan pemerintah. Sedangkan penyajian datanya dilakukan dengan analisis statistik (Sugiyono,2017). Penelitain ini untuk menguji pengaruh mobile banking, internet banking dan sms banking terhadap kinerja keuangan perbankan syariah di Indonesia. Menurut (Sugiyono, 2017)menyimpulkan bahwasanya sample ialah ukuran dan karakteristik populasi, jika populasi yang dimiliki besar dan peneliti tidak mungkin mempelajari segala sesuatu yang ada dalam populasi tersebut, misalnya karena keterbatasan dana, tenaga dan waktu, peneliti dapat menggunakan sample yang diperoleh dari populasi tersebut. Kesimpulan yang dipelajari dari sample akan ditetapkan pada populasi oleh karena itu, sample yang diambil dari populasi harus benar-benar representatif. Sample yang dijadikan objek dalam penelitian ini yaitu bank umum syariah yang telah menggunakan layanan fintech seperti mobile banking, internet banking dan sms banking yang telah mempublikasikan laporan keuangan dari waktu ke waktu penelitian selama periode 2015-2020.

Menurut Sugiyono (2017), populasi adalah bidang yang digeneralisasikan, yaitu terdiri dari objek atau subjek dengan kualitas dan karateristik ditunjuk oleh peneliti untuk penelitian dan kemudian ditarik kesimpulannya. Jadi populasi dalam penelitian ini adalah seluruh laporan keuangan yang dikeluarkan oleh Bank Syariah yang sudah menggunakan financial technology yaitu Bank BNI Syariah, Bank BRI Syariah, Bank Syariah Mandiri, Bank BCA Syariah, Bank Syariah Bukopin dan Bank BJB Syariah periode 2015-2020. Teknik ini bertujuan untuk mendapatkan sampel yang sesuai dengan kebutuhan penelitian. Maka sampel dalam penelitian ini adalah Bank BRI Syariah, Bank BNI Syariah, Bank Syariah Mandiri, Bank BCA Syariah, Bank Bukopin Syariah dan Bank BJB Syariah periode 2015-2020 yang sudah di publIkasikan. Dalam melaksanakan penelitian penulis melakukan telaah literatur dengan merujuk pada dokumen yang relevan dengan topik penelitian. Berbagai informasi diperoleh untuk mengungkap isu dan menyusun konsep yang akan digunakan. Kegiatan ini meruapakan awal dari keseluruhan penelitian yang dilakukan. Teori ini diperoleh dari buku, jurnal maupun skripsi. Metode ini digunakan untuk mempelajari dan memahami literatur-literatur yang berkaitan dengan penelitian ini.

\section{HASIL DAN PEMBAHASAN Uji Normalitas}

Uji normalitas bertujuan untuk mengetahui apakah hasil nilai residual yang telah dihasilkan terdistribusi secara normal atau tidak, maka dapat dilakukan dengan uji statistik non-parametrik kolmogorov- smirnov. Pada metode pengujian normal jika nilai signifikan lebih besar dari 5\%, maka menunjukkan distribusi normal. Berdasarkan hasil analisis data menggunakan metode kolmogorov- Smornov test didapatkan hasil signifikan dan uji normalitas pengaruh variabel $\mathrm{x} 1$, x2, dan x3 terhadap variabel y sebesar 0,200. Diaman hasil tersebut lebih besar dari 0,05 sehingga dapat disimpulkan penelitian terdistribusi normal.

\section{Uji Heteroskedastisitas}

Dalam melakukan suatu penelitian uji heteroskedastisitas sangat penting digunakan, sehingga pada penelitian ini menggunakan uji Glejser untuk mengetahui apakah terjadi heteroskedastisitas dalam penelitian ini, dengan mengahasilakan output dari porgram SPSS v23. Hasil pengujian heteroskedastisitas menunjukkan bahwa tidak ada satupun variabel 
independen yang signifikan secara statistik mempengaruhi variabel dependen nilai Absolut. Hal ini terlihat dari probabilitas signifikannya diatas 5\%. Jadi dapat disimpulakn model regresi tidak mengandung adanya heteroskedastisitas. Berdasarkan uji yang dilakukan heteroskedastisitas menyimpulkan bahwa variabel X1 (mobile banking) angka signifikannya senilai 0,353 >0,05, sedangkan X2 (internet banking) dengan nilai signifikan sebesar 0,344 > 0,05 dan X3 (sms banking) dengan nilai signifikan sebesar 0,352 >0,05, sehingga dapat disimpulkan dari keseluruhan variabel tidak terjadi heretoskedastisitas.

\section{Uji Multikolinearitas}

Dalam melakukan uji multikolinearitas didalam penelitian ialah untuk mengetahui apakah terdapat korelasi yang tinggi antar variabel idependen didalam uji regresi yang digunakan. Serta untuk mengetahui terdapat atau tidak multikolinearitas didalam uji regresi yang dilakukan dengan melihat dari nilai tolerance berlawan dan Variance Iflancy Faktor (VIF). Jika nilai VIF kurang dari 10,00 dan nilai tolerance lebih dari 0,10 maka dapat disimpulkan bawha regresi yang digunakan bebas dari multikolinearitas. Berdasarkan uji yang dilakukan dengan menggunakan spss v23 variabel X1(mobile banking) dengan nilai tolerance sebesar 0,997 > 0,10 dan nilai VIF $1,003<10,0$, variabel X2(internet banking) dengan nilai tolerance sebesar $0,997>0,10$ dan nilai VIF 1,003 < 10,00 dan variabel X3(sms banking) dengan nilai tolerance sebesar 0,997 > 0,10 dan nilai VIF 1,003 < 10,0, sehingga dapat disimpulkan pada penelitian ini tidak terjadi multikolinearitas.

\section{Uji Autokorelasi}

Uji autokorelasi bertujuan agar mendapati apakah terdapat korelasi antara kesalahan penganggu suatu observasi dengan pengganggu yang lain. Dengan demikian, model regresi yang baik adalah yang tidak terjadi autokorelasi dengan melihat nilai Durbin Watson. Berdasarkan uji regresi hasil dari Durbin Watson menunjukkan 1,530 dengan jumlah observasi (N) sebanyak 108. Sehingga dapat dilihat nilai DL dan DU pada tabel Durbin Watson dengan nilai DL 1,6297, nilai DU 1,7437, nilai 4-DL 23703 dan nilai 4-DU 2,2563. Berdasarkan hasil uji autokorelasi durbin watson menghasilkan nilai DW $\geq$ nilai DU dan nilai DW $\leq 4$-DU yaitu sebesar 1,530, maka dapat disimpulkan $\mathrm{H} 0$ diterima yang artinya tidak terdapat gejala autokorelasi pada data yang digunakan untuk penelitian.

\section{UJI HIPOTESIS Uji T (Partsial)}

Dalam melakukan uji t ini memiliki tujuan untuk mengetahui apakah variabel independen yang digunakan mempunyai pengaruh secara partial terhadap variabel dependenya. Hasil t diatas dapat diketahui hasil uji hipotesis secara partial, yaitu :

Pengaruh mobile banking terhadap kinerja keuangan pada perbankan syariah di Indonesia Variabel mobile banking(X1) memiliki nilai signifikansi 0,566 $<\alpha 0,05$ dapat disimpulkan H01 di tolak dan Ha1 diterima, hal ini menunjukkan bahwa mobile banking berpengaruh signifikan secara partial terhadap kinerja keuangan perusahaan pada perbankan syariah di Indonesia.

Pengaruh internet banking terhadap kinerja keuangan pada perbankan syariah di Indonesia Variabel internet banking(X2) memiliki nilai signifikan 0,469 $<\alpha 0,05$ dapat disimpulakan $\mathrm{H} 02$ ditolak dan $\mathrm{Ha} 2$ diterima, hal ini menunjukkan bahwa internet banking berpengaruh signifikan secara partial terhadap kinerja keuangan perusahaan pada bank syariah di Indonesia. 
Pengaruh sms banking terhadap kinerja keuangan pada perbankan syariah di Indonesia Variabel sms banking(X3) memiliki nilai signifikansi 0,404 $<\alpha 0,05$ dapat disimpulkan H03 di tolak dan Ha3 diterima, hal ini menunjukkan bahwa sms banking berpengaruh signifikan secara partial terhadap kinerja keuangan perusahaan pada perbankan syariah di Indonesia.

\section{KESIMPULAN}

Berdasarkan hasil analisis yang telah diuraikan pada bab sebelumnya, dapat disimpulkan bahwa Mobile banking berpengaruh signifikan terhadap kinerja keuangan perbankan syariah di Indonesia. Sehingga dapat disimpulkan bahwa semakin tinggi tingkat signifikan hubugan antara moble banking terhadap kinerja keuangan maka akan semakin positif pula kinerja keuangan perbankan syariah di Indonesia. Internet banking berpengaruh signifikan terhadap kinerja keuangan perbankan syariah di Indonesia. Sehingga dapat disimpulkan bahwa semakin tinggi tingkat signifikan hubungan antara internet banking terhadap kinerja keuangan maka akan semakin positif pula kinerja keuangan perbankan syariah di Indonesia.Sms banking berpengaruh signifikan terhadap kinerja keuangan perbankan syariah di Indonesia. Sehingga dapat disimpulkan bahwa semakin tinggi tingkat signifikan hubungan sms banking terhadap kinerja keuangan perbankan syariah di Indonesia.

\section{DAFTAR PUSTAKA}

Arsita, Y. (2021). ANALISIS RASIO KEUANGAN UNTUK MENGUKUR KINERJA KEUANGAN PT SENTUL CITY, TBK. 2(1), 152-167.

asnawi, w. a., rate, p. van, sam, u., \& manado, r. (n.d.). pengaruh kinerja keuangan bank terhadap return on asset ( roa ) studi pada bank umum devisa buku 4 the influence of bank financial performance to return on assets ( roa ) study in commercial banks foreign exchange book 4. 6(4), 2898-2907

Amali, L. M., \& Gorontalo, U. N. (2021). PENGARUH E-BANKING TERHADAP KINERJA KEUANGAN. 3(0411), 36-47.

Car, P., Dan, F. D. R., Terhadap, B., Pada,P., \& Syariah, U. (2019). Jurnal administrasi dan perkantoranmodern. 2013, 10-22.

Fianto, C. K. R. dan B. A. (2020). analisisdeskriptif dimensi kualitas layananmobile banking (M-BANKING) terhadap kepuasan nasabah perbankan syariah. 7(6), 1118-1127. https://doi.org/10.20473/vol7iss20206pp1118-1127

Hiyanti, H., Nugroho, L., Sukmadilaga, C., Fitrijanti, T., Buana, U. M., \& Syariah, F.(2019). Jurnal Ilmiah Ekonomi Islam , 5 ( 03 ), 2019, 326-333 Peluang dan Tantangan Fintech ( Financial Technology) Syariah di Indonesia. 5(03), 326-333.

Islam, U., \& Walisongo, N. (2018). THE ROLE OF SPIRITUALITY IN THE BEHAVIOR OF SHARIA BANK MOBILE BANKING : EVIDENCEFROM INDONESIA. 26(1), 197-224.

Lutfi, A. M., \& Sunardi, N. (2019). PENGARUH CURRENT RATIO ( CR ), RETURN ON EQUITY ( ROE), DAN SALES GROWTH TERHADAP HARGA SAHAM YANG BERDAMPAK PADA KINERJA KEUANGAN PERUSAHAAN ( Pada Perusahaan 
Manufaktur Sektor Makanan dan Minuman Yang terdaftar di Bursa Efek Indonesia). 2(3), 83-100.

Meslier, C., Risfandy, T., \& Tarazi, A.(2020). Islamic banks ' equity financing, Shariah supervisory board, and banking environments. Pacific-Basin Finance Journal, 62(April), 101354. https://doi.org/10.1016/j.pacfin.2020.101354

Moridu, I., Ekonomi, F., Bisnis, D., Muhammadiyah, U., Banggai, L., Banggai, L., Tengah, S., \& Banking,

D. (2020). PENGARUH DIGITAL BANKING TERHADAP NILAI PERUSAHAAN PERBANKAN ( StudiPada PT . Bank Negara Indonesia ( Persero ) Tbk ). 3(2), 67-73.

Muhammad, H., \& Sari, N. P. (2020). Pengaruh Financial Technology Terhadap Perbankan Syariah : Pendekatan ANP-BOCR ( The Influence of Financial Technology on Islamic Banking: ANP-BOCR Approach ). 4(2), 113-125. https://doi.org/10.21070/perisai.v4i2. 868

Manajemen, J. E. (2018). ANALISA PENGARUH MOBILE BANKING TERHADAP KINERJA PERUSAHAAN SEKTOR PERBANKAN YANG TERCATAT DI BURSA EFEK. 4(November), 96- 107.

Priyanto, D. (2013) Mandiri Belajar Analisis Data Dengan SPSS. Yogyakarta: Medikom

Sinambela, E. (2017). FORUM KEUANGAN DAN BISNIS INDONESIA ( FKBI ) pengaruh Penyediaan Layanan Internet Banking Terhadap Kinerja Keuangan Perbankan di Bursa Efek Indonesia. 87-94.

Supit, T., Tampi, J. R. E., \& Mangindaan, J. (2019). Analisis Perbandingan Kinerja Keuangan Bank Bumn Dan Bank Swasta Nasional Yang Terdaftar Pada Bursa Efek Indonesia. Jurnal EMBA: Jurnal Riset Ekonomi,Manajemen, Bisnis Dan Akuntansi,7(3), 33983407.

Wijayati, C. D., \& Gustyana, T. T. (2021).The Impact of Mobile Banking on ROA of Islamic Banking Which was Listed on The IDX in 2015-2019. 3(1), 63-69. 